\title{
CULTURAL TABOO IN ADVERTISING. DIFFERENCES IN THE TRANSMISSIONS OF AUDIOVISUAL ADVERTISING IN AMERICAN AND HINDU MARKET Magdalena Hensoldt-Fyda ${ }^{1}$
}

\begin{abstract}
The aim of this article is to examine differences between the transmissions of advertising content in the low and high context culture where the content contains subjects that are widely recognized as taboo. In order to do this, the analysis of audiovisual advertisements broadcast in the USA and India was used. These adverts introduce the problem of gender discrimination (particularly important in Hindu society) and different approach to gender stereotypes in both cultures (in American culture this subject is not suppressed). There are contrasting ways of presenting these difficult subjects in American and Hindu cultures. The things that are taboo in one culture become a stereotype in the other. And so, the question arises: do the cultural differences determining transmission of advertising content in the countries with cultural taboo of a product on sale still exist?
\end{abstract}

Keywords: cultural taboo, culture of low and high context, communication style, transmission of advertising content.

\section{Introduction}

This article was created to prove the existence of differences between audiovisual advertisings broadcast in two cultures - the low context culture, in this case represented by American culture, and the high context culture characteristic for Indian society. Each of these cultures displays the set of specific traits, which originate from the style of communication accepted by these societies. The differences mentioned above are clearly visible in advertisement transmissions referring to taboo subjects, which in other words are the subjects that should not be spoken of in certain societies. There are some boundaries in each culture and community that should not be crossed or people simply do not want to cross them. Good taste in advertising is set by specific cultural conditioning. Although there are, more and more instances of breaking taboo which results in positive changes in thinking and behaviour as well as cultural changes in these societies, in case of advertising it is more about pushing the social boundaries. Companies such 
as Procter\&Gamble are among the groups that create taboo breaking advertisements using sensitive and even shocking themes.

This article has a review-analytic character and its goal is to analyze advertising spots that focus on subjects such as gender inequality and sexuality. Each of these subjects was put in a different cultural context. The United States was chosen for the analysis as the most characteristic representative of the low context culture and India as the example of the high context culture, which is very hermetic, euphemistic and mysterious. The first part of the article focuses on theoretical aspect of the term taboo, whereas in the second part the essence of the high and low cultural context is thoroughly analyzed. The second chapter also discusses selected aspects that refer to the transmission of advertising contents. The essential part of this article is an analysis of audiovisual advertisings broadcast in American and Indian market, which have recently raised socially important subjects. The summary of the article includes a short ending with conclusions.

\section{Cultural taboo - theoretical formulation}

"Taboo" is a word generally understood as the deep and fundamental cultural prohibition. This phenomenon functions in each society in a different way. It is differently called, formulated and understood. Taboo "is a group of attitudes about very heterogeneous and internally contradictory characterization" [Wasilewski of 2010, p.11]. The word "taboo" was introduced and universalized by the traveller - captain James Cook in the second half of the 18th century. The first mentions about taboo appeared around ten to twenty years after the Cook's journal was issued. For the first time taboo was defined by The English Dictionary in 1791, as a forbidden area." Taboo was also associated with the term "familiar cultural reality" [Wasilewski, 2010, p.17-18] Taboo also consists of everything that people make, think and possess [Sztompka, 2012, p.291].

The cultural taboo can be described as enforced prohibitions imposed by a certain social group, community or the whole society. In other words, it is an external prohibition, which is connected with two terms: the consequence of avoidance or negative consequence. Cultural taboo exists where the external prohibition does not exist, and the reasons for the avoidance of taboo subject lie in its quasi-objective properties. [Panasiuk, 2009, p.284]. The creation of taboo is decided by individual orders. Just because some people functioning in a particular culture react to a certain subject with silence does not mean that all of them will react in the same way. This rule applies to the whole community. In other words, "taboo is a cultural occurrence including everything, that is enfolded by social prohibition (at times also legal); these are behaviours that are not acceptable, and subjects that should not be discussed in communities (it is improper to mention them), because they are seen as embarrassing, dangerous, controversial, unpleasant or immoral" [Dąbrowska, 2008, p.175].

Cultural taboo is connected with beliefs, convictions, rules, values, standards and norms accepted by certain societies. There are differences between them depending on the history of community, customs, cultivated traditions, religions and habits distinctive for the whole society. Avoidance of taboo is caused by religious beliefs, magic, fear, decency, modesty, shame or good upbringing. All these individual features are the result of culture, which has an influence on human beings since their birth. The violation of taboo results in huge social sanctions. Taboo revolves around different cultural conditioning and it mostly belongs to a social zone which means that it is imposed by society, and to violate it can cause personal or group consequences [Afek, 2013, p.20-22].

The relation between taboo and culture is a variable. Taboos create prohibitions. These prohibitions are the result of culture. It is impossible to include them into a system and describe them as true for each community. Taboo prohibitions are not justified, and their origin is not entirely explained. What is more, taboo creates a certain symbolic border between what is good and what is not, what is religious and what is not. This is a 
cultural category in the process of the arrangement of the world, giving it sense and integrating it. This category keeps and modifies the identities of social groups. Simultaneously, it protects people from foreign influences and evokes fears, bad taste and at times simply repugnance. It emphasizes the existence of something unsuitable, something that requires silence and omission [Mach, 2002, p.172]. Taboo is also an important part of a social identity. The adoption of a certain identity means acceptance of taboo and of the social norms characteristic for a particular community [Fiske, Tetlock, 1997, p.255].

The term taboo is strictly connected to the so-called breaking taboo. This is nothing less than breaking of an unwritten rule about crossing the cultural barriers, which were not publicly spoken about. Nowadays, the best catalyst for taboo displacement from the culture is media. Fast social development, globalization and practically unrestricted access to the media, creates a great environment for breaking taboo. Media became a serious threat to taboos and gave the opportunity to raise sensitive subjects. However, the ease of breaking taboo does not refer to all aspects of everyday life. It is necessary to mention, that sometimes together with breaking cultural taboo extreme emotions and reactions such as aggression, lack of acceptance, but also approval and excitement arise. Suppressing taboo leads to the creation of new rules and cultural values as well as creation of other areas dealing with prohibitions. What is more, taboo cannot disappear entirely. It exists as long as it evokes the feeling of guilt [Cudny, 2012, p.41].

To summarize, taboo as social phenomenon evolved together with the development of society. Initially, it referred to the sphere of beliefs among primitive cultures, but contemporarily it is used to indicate subjects that should not be discussed. Taboo is also used to describe everything that should not be publicly expressed. "Taboos are sometimes referred to as doing the "unthinkable." Even thinking about violating a taboo is problematic. The sanctions associated pertain not just to the behaviour that contradicts the taboo, but also to merely thinking or considering such a behaviour. According to this interpretation, a taboo is a form of "thought police" that governs not just human behaviour, but also its thoughts" [Fershtman, Gneezy, Hoffman 2011, p.140]. This way of understanding cultural taboos is a basis for more in depth analysis in this research paper. Taboo became an element of advertising transmission through euphemization of contents.

\section{The high and low context culture as the attribute of advertising transmission}

Culture is the element of social life, which is closely related to communication. In other words, culture serves communication. It is created and developed due to interpersonal relations, where individuals deliver different information and teach each other how to react to it in various circumstances. Following this assumption, it is possible to divide culture into two categories of high and low context. The creator of this theory was Edward Hall who in 1976 proposed a contextual model, introducing two kinds of communication - communication about the low role of context in the reception of the messages and communication about the high role of context in the reception of the messages [Nishimura, Nevgi, Tella 2008, p.784]. "The cultures of the world can be compared on a scale from high to low context" [Hall \& Hall, 1987, p.6].

In the low context culture, the message must be very detailed. It should contain as much additional information as possible in order to be properly interpreted. The message has to be clear, univocal and precise. There is no place for various interpretations. Low context communication is mainly based on spoken and written language and puts emphasis on the exchange of facts and information. The broadcaster is more important than the receiver. Culture is focused on the individual. At the same time the social and occupational position does not matter. Moreover, low context is suitable for people with independent identity. This is "typical of task-oriented cultures, in which honesty is an important value and direct communication is supposed to be on the shortest path to a pragmatic goal, achieving something particular or completing a certain task [Boski, 
2009, p. 231]. Countries such as Germany, the United States of America and Great Britain represent low context culture.

The high context, on the other hand, is completely different and is often characterized by indirect manner of formulation and expression of thoughts. Besides spoken and written language, there is body language, social position and knowledge about mutual relationships, which are very important elements of non-verbal communication. High context contains information full of ambiguous meanings. The broadcaster's expectations of receiver are not clearly defined and often only signaled, therefore communication is required to deliver information through gestures or situational context. The form of statements is cautious and polite. Broadcaster and receiver have equal contribution to the quality of the process of communication. The form of delivered information is more polite and careful. In cultures of high context, the social and occupational status is much more important. Interpersonal interactions are characterized by large dose of conservatism. Moreover, during the communicative exchange of high context, the interactions are accompanied by silence because they do not rely on verbal communication as their main source of information. What is interesting, is that the silence between people indicates the higher status of the other culture [Weider, Pratt, 1990, p.48]. High context cultures include Arabian countries, Western Europe, India and Japan.

It is important to mention, that it is not possible to classify all cultures in terms of low and high context culture. There are some countries which are described as the middle cultural context. These countries have characteristics of low and high context culture - for example the countries of Central Europe. Their inhabitants are people who do not like silence but they like to focus in small groups, are full of vigor, have rich body language and retain formal social relations [Brett, 2001, p.33-35].

Cultural differences shape every aspect of global communication. According to $E$. T. Hall "a high context communication or message is one in which most of the information is already in the person, while very little is in the coded, explicit, transmitted part of the message. Low context communication is just the opposite" [Hall \& Hall, 1987, p.6]. Moreover, language, as the medium of culture, constitutes the key part of culture. It possesses unique cultural connotations. It means that people in India prefer face-to-face communication over electronic technology favored in other industrialized countries like the United States. These two countries are different in every aspect. That is the reason, for which those two countries were selected as an example.

The American culture possesses an unusual mixture of patterns and forms forged from its diverse American population. What is interesting "the American culture and technological progress are implemented worldwide" [Cismas, 2010, p.392]. What is important is that the American culture is an example of cultural pluralism. For instance, there are still some Native Americans with their own language, culture and traditions. Many Americans have German, Irish, Jewish, Asian, Indian and Scandinavian roots. It makes the American culture an unusual mixture, which created society that struggles to achieve tolerance and produces a uniquely casual personal style [Cismas, 2010, p.388]. On the other hand, people in the USA have become very sensitive to the language when they have to describe racial or ethnic groups and they try to be politically correct. This makes the American style of communication increasingly careful and requires the use of a large number of words.

There is a stereotype about American culture not accommodating high values and being immersed in popular culture. The American pop culture is known in the entire world. Films, music, blue jeans, Coca-Cola - the attributes of culture, which is very individualistic, promotes mobility and exacting attitudes of personal initiative. Americans are flexible and open. Materialistic values and account balances are more important for them than their social status. In direct communication, broadcaster and receiver are equal. They very quickly start to use words such as "you" when they speak to someone. They speak, but not always listen. They live in a moment, their maxim is "everyone differ- 
ent, but all equal". They put themselves in the center of attention. These characteristics make American culture the best example of the low context culture [Cohen, 1997, p. 3033].

Communication styles in the Unites States are energetic and positive. Inhabitants of America usually speak in the present or imperative tense with lots of action-oriented words, example "do it", "make it" etc. Many powerful words and expressions are used as well, including: greatest, excellent and similar. Americans are well known for their positive thinking. They do not complain and use the word challenge instead of problem. They are friendly, open and direct in their communication. What is more, there are few words in English language expressing uncertainty. The language of low context is immediate and clear. Personal pronoun "I" is used often. Americans value facts and they are trying to show reality more realistically. Thoughts have logical sequence. They put words into action [Zięba, 2008, p.254].

The culture of India, which is one of the oldest in the world, is characterized by completely different features. Community culture is very important in India. This means that honor, family affairs, groups or even caste system is much more important than the individual. Community life requires loyalty to society more than to the country...

Culture plays an important role in India and it functions as the social control. There is no anonymity in small communities. People can co-decide about their neighbors' life choices. Patriarchate dominates in India. Father as the head of family decides about fate of his children. The whole family has to follow his instructions. Women are perceived as not self-reliant individuals and without the agreement of the male family member, they are not permitted to make any life decisions. "Indians are extrovert, talkative, emotional, and unpunctual, and they mix professional and family affairs" [Nishimura, Nevgi, Tella 2008, p.793].

"In the cultural sphere India seems to be thrown into the world of a magical charm. (...) The spirituality of India attracted esoteric groups focusing on an Indian guru. Now a Bollywood and other Indian pop culture items have reached young people around the world, and the impact probably will increase in subsequent years. [Rothermund, 2010, p.289-290]. In spite of everything, this unusual cultural mosaic makes India representative of high context culture.

Indian style of communication is branded by patience, harmony and pragmatism. Hindu society is hierarchic. They never forget about hierarchy when communicating. They use titles emphasizing social status. They are convinced, that having a higher place on a social ladder means they know more and they have more rights. "Indians are highly collectivist in their local group, but individualistic when dealing with outsiders" [Nishimura, Nevgi, Tella 2008, p.793]. They tend to have greater need for formal rules, standards and structures and tend to avoid conflicts, seek consensus and take fewer risks. However, deviation from these rules and standards is considered disruptive and undesirable. This table presents a comparison of the most important aspects of differences between American and Indian styles of communication.

\begin{tabular}{|l|l|l|}
\hline $\begin{array}{l}\text { COMMUNICATION STYLES' } \\
\text { ASPECTS }\end{array}$ & AMERICANS & INDIANS \\
\hline eye contact & $\begin{array}{l}\text { fleeting, eye contact is for } \\
\text { the speaker }\end{array}$ & $\begin{array}{l}\text { prolonged when speaking, } \\
\text { less so when listening }\end{array}$ \\
\hline gestures & $\begin{array}{l}\text { gestures in normal conver- } \\
\text { sation are typical }\end{array}$ & $\begin{array}{l}\text { large gestures are norma- } \\
\text { tive }\end{array}$ \\
\hline
\end{tabular}




\begin{tabular}{|c|c|c|}
\hline $\begin{array}{l}\text { COMMUNICATION STYLES' } \\
\text { ASPECTS }\end{array}$ & AMERICANS & INDIANS \\
\hline identity orientation & $\begin{array}{l}\text { an individualism orienta- } \\
\text { tion, located within the indi- } \\
\text { vidual person }\end{array}$ & $\begin{array}{l}\text { decisions are made with- } \\
\text { in the context of the group } \\
\text { and by assessing how the } \\
\text { action will affect others in } \\
\text { the collateral identity group }\end{array}$ \\
\hline turn taking and pause time & $\begin{array}{l}\text { turn taking is signaled by } \\
\text { the speaker looking directly } \\
\text { at the listener and ceasing } \\
\text { to speak; pause time is very } \\
\text { brief }\end{array}$ & $\begin{array}{l}\text { turns are taken when the } \\
\text { speaker is moved to speak; } \\
\text { speaking too quickly after } \\
\text { the previous speaker may } \\
\text { be seen to indicate that the } \\
\text { next speaker }\end{array}$ \\
\hline touch & $\begin{array}{l}\text { touch is so rare as if virtual- } \\
\text { ly non-existent }\end{array}$ & $\begin{array}{l}\text { reserved for friends or inti- } \\
\text { mates }\end{array}$ \\
\hline use of language & $\begin{array}{l}\text { informal, friendly, use first } \\
\text { name }\end{array}$ & $\begin{array}{l}\text { formal, expression of admi- } \\
\text { ration }\end{array}$ \\
\hline preferred topics & $\begin{array}{l}\text { weather, sports, jobs, peo- } \\
\text { ple they both know, or past } \\
\text { experiences }\end{array}$ & $\begin{array}{l}\text { family, celebrities, travel, } \\
\text { proudly Indian }\end{array}$ \\
\hline body language & open body positions & sit quietly \\
\hline attention to detail & high & low \\
\hline $\begin{array}{l}\text { preferred communication } \\
\text { strategy }\end{array}$ & $\begin{array}{l}\text { directness, confrontation, } \\
\text { clarity }\end{array}$ & $\begin{array}{l}\text { indirectness, politeness, } \\
\text { ambiguity }\end{array}$ \\
\hline
\end{tabular}

source: Elliot 2010; Elashmawi and Harris 1998, p.113; Victor 1992, p.148.

Cultural differences are reflected not only in the styles of interpersonal communication but also mass communication. The best example is an advertisement which is aimed at a particular receiver. The efficient advertising should contain intriguing promise to make it more believable. To do that, the creators of advertisements make use of both picture and sound. It is known that image in advertising transmissions plays a superior role However, the majority of transmissions still require the participation of written or spoken language. "World of advertising, beautiful and euphoric to which the receiver is to enter can easily be shown in different ways but is fully realized with an addition of word" [Bralczyk 2004, p.11].

Undoubtedly, advertising is an element of culture. "It reflects like in the mirror barely noticeable changes in the values, morals and the behaviours of social groups, to which it aims its transmission (...) it is possible to notice indirect information about how receiver should perceive and identify reality, what sort of relationship with other people should he has, in relation to himself" [Russel and Lane 2000, p.34-35]. It is possible to define advertising as a form of transmission with very efficient means of persuasion. It indicates that the broadcaster can determine and condition the reception of advertising, modifying experiences of a receiver and changing his sales habits and attitude.

The reception of advertising transmissions in the high and low culture context is similar to the styles of communication described above. In the American culture, the news has to be clear and detailed and the same idea is implemented in advertising, where receiver clearly understands the intention of the broadcaster. In the Indian advertising, the subject of taboo is not presented directly. There is a great deal of symbolism in them and they are understood nearly exclusively in a particular cultural circle. Independently from the context, Indian advertising creates the idea seemingly better than the real world. Usually it idealizes its people, ideologies, behaviours or objects, giving them completely fictitious traits. These aspects exist in the majority of advertisements. 
Nevertheless, it is necessary to remember, that the influence of the advertising can deform certain values, which in time lose meaning, and the new meanings, serving mainly persuasion and possessing the shock value appear in their place. Additionally, advertisements create a delusion of self-realization.

The most important difference between the transmission of advertising in India and the United States is that American society treats advertising as polytheistic religion. This means that for materialistic Americans advertised products are like deities. They want to possess as much as possible and their contact with material goods is comparable to Hindu spiritual relationship with deities. In American society, the function of culture in advertisement is to produce things and their meanings. What is more, "contemporary advertising is the most powerful propaganda system in the world" [Duda, 2005, p.40]. Regardless of the context, which accompanies advertisement "it plays a big role in the development of human thoughts and behaviours. Ignoring cultural differences in an interaction can potentially signal trouble" [Salleh 2014, p.1].

Taking into consideration the assumptions, the transmissions of advertising including taboo subjects on the Indian and American market will be analyzed thoroughly in the following part of the article.

\section{The cultural taboo in Indian and American advertisement- introduction}

The intentions of broadcasters differ to a considerable degree from the expectations of the receivers in the advertising transmissions. The first one wants the contents of advertising to be difficult to discredit, whereas the latter wants the content to be true. In reality, the content seems to be credible at most. The way that advertising introduces reality does not have to be real. These are so-called relational features, which constitute a relation between the text (of contents) and the reality [Bralczyk, 2004, p.37]. Therefore, advertising should be attractive, suggestive, understandable, easily remembered, concise and original. From a point of view which is presented in this article, these features are differently understood by the different communities, and the catalysts of their comprehension are cultural contexts that had been described above.

In each community, taboo is comprehended in a similar manner but can refer to completely different things. Things that are normal for some, for others can be forbidden. Subject such as freedom of sexes, is one of the examples. There are equal rights between women and men in America. Since 1920 when the 19th amendment to the Constitution introduced women's right to vote during the election, they have begun to be more and more liberated and equal to men. The so-called liberation from gender stereotypes took place although in many situations women were still considered as a weaker sex (mainly on the job market). American women are responsible and are able to take autonomous decisions and to solve majority of their own problems as well as their family [Leśniak-Moczuk, 2015, p.67]. In American society the equal rights are not a taboo subject.

This subject is treated very differently in India. In this country, contemporary modern culture clashes with traditional culture based on patriarchate. For centuries, two opposite models on the subject of treatment of women have been clashing together. Women were goddesses, servants, saints and harlots. For hundreds of years, marriage used to be the greatest honor for women. What is more, marriage and bearing children is an absolute necessity. In Hindu culture there is a very clear division between male and female roles. Equal rights are seen as a western ideology and an exotic concept. Therefore, the subject of the equal rights of women should never be discussed in India.

Advertising is not familiar with the definition of taboo. Since there is a mass communication for the anonymous receiver, advertising becomes one of the best tools to suppress cultural taboo. Social changes result mainly because of the democratization and liberalization in everyday life. A commercial advertisement fits perfectly to this de- 
scription because it does not break the taboo but it provokes receivers to reflect on it. For example, Eastpak has depicted death in their advertising campaigns. Sisley has represented various deviating sexual practices like sadomasochism and United Colors of Benetton (starting from 1991) evoked the sentiment and the compassion of the public for different social problems. The most well-known motifs of Benetton's advertising were: a dying AIDS patient, a priest kissing a nun, an H.I.V. positive and child labor [Guardian Fashion, 2011]. Then there is the question: what does breaking the taboo of women's equality look like in India? Does a similar problem exist in America at present?

\section{The equality of gender in advertising - differences in the transmission be- tween American and Indian adverts}

Advertising creates an opportunity for a change in terms of women's role in India. In recent years, changes in Indian advertising can be observed. These changes are a direct result of Western influences. Some brands existing on the Indian market promote positive changes that reflect and strengthen changes in the society. The example of such advertising is an advertisement campaign of a company called Whisper, which produces sanitary napkins and is a part of a worldwide brand called Procter\&Gamble. Their advertising spots were screened in India in 2014 [WhisperIndia, 2014]. The plot of a particular short spot refers to a local superstition, which says that a woman during the menstrual period should not touch a container with pickles, because it will cause food spoilage and will bring bad luck to other home-dwellers. The main character in the spot is a young girl, who rebelliously performs forbidden activity and encourages other women to do the same. "Touch the pickle." The woman shows, that nothing bad happens. The woman is well protected by the napkins she uses. The meaning is literal but also symbolic. Literal$l y$, it means that these napkins are absorptive and give comfort. Symbolically they protect her from the results of taboo breaking. The girl was active all day long and nothing bad happened. She wins a game of tennis triumphantly proclaiming that she "touched the pickle". This advert became the symbol of overcoming superstitions discriminating women, which are very common in Indian culture [Bienias, 2016].

Having succeeded, Procter\&Gamble created another advertisement in 2015. This time it was about laundry detergent called Ariel entitled "Watch How Men Responded to." The theme of this advertisement focused on distribution of domestic duties in India. Research conducted by P\&G indicates that $85 \%$ of working women have a second job in the house, but $76 \%$ of men think that washing is a domestic responsibility of a woman [BBDO India, 2015]. The short spot begins with the conversation between two older women. They recall their youth and they talk about the changes that happened in the last several years. One of them, with disbelief, but also with the hint of pride states, that her daughter-in-law earns more than her son. In this short conversation, they praise cultural progress in their country. Unexpectedly, a young man appears on the stairs. He greets his wife with a question: Why didn't you laundry my shirt?" The creators of this advertisement describe it in these words: „A new action-oriented movement idea for Ariel that aims to discuss a latent but simmering tension point in society: Is laundry only a woman's job? Wouldn't it be great to build a society where husbands and wives share the load? Because where there is equality there is true happiness" [BBDO India, 2015]. Apart from the humorous advertising Procter\&Gamble designed the instructions for application of laundry detergent, especially with men in mind. The campaign results exceeded all expectations. It turned out that the idea for the campaign was supported by more than 1.5 million men, and sale was increased by $60 \%$ [Bienias, 2016].

In 2016, an agency called "BBDO India" decided to continue Ariel's campaign, creating an advertising spot that provoked strong emotions. This time the hero was an older man observing a daughter after returning from her work. He sees how she always speaks on the phone about her work and at the same time serves her husband tea, cooks dinner, picks up toys and finally after her husband asks the question “Why didn't you laundry my 
green shirt?" she starts doing it. The saddened father looks at the situation and writes a letter to her in which he apologizes her daughter, admitting that nowadays she must do everything alone. He says: "I'm sorry. I never told you that it's not your job alone... but your husband's too. But how could I say it... when I never helped your mom either. And what you saw, you learnt. Your husband must have learned the same from his dad. Sorry on behalf of every dad who set the wrong example". This moving confession shows how important is the problem of discrimination. This stereotype in Hindu culture, demands from women to do all of the housework, and give men more time to rest. Without a doubt, the creators of this advertisement raised a socially important subject. They broke taboo about gender stereotypes. This father's heart-warming apology to his daughter will make you wonder, 'Are we passing on gender roles that haven't evolved with the times?' Maybe it's time to \#ShareTheLoad [BBDO India, 2016].

But what does the problem of gender discrimination look like in the United States? It turns out that women rights are neglected and there are stereotypes in American society as well. Women have a lower position on a social ladder than men do. These are social problems, which social campaigns focus on. This raises the question: Is the taboo subject relating to equality of gender being broken in American commercial advertising? It appears that in an economically well developed country such as the United States of America, which is more progressive and liberal than India these stereotypes are the same. They are not in the same group of taboos that exists in an advertisement but they are worth mentioning in order to understand the situation of women in the United States better. In American culture a woman is a homemaker and a man is the head of a family and other members of the family should be subordinated to him. Women are pressured to cook healthy food in order to show love for their families. When in reality, it is not the only way to show love and support. Generally, women are devaluated in America. Society expects that they will take care of the house, and their only responsibility is to serve the family. In the advertisements, women serve Coca-Cola during the family meal prepared also by them. Women do the washing-up and walk the dog while the remaining family members watch television. Finally, they clean up remains after the dinner/party/friend's visit. All these advertisements show how deeply rooted these stereotypes became in the American culture. Women suffer from stereotypes about food. Unhealthy food is served only by an unloving mother. Therefore, women must be creative in the kitchen and they should be satisfied with this position in the family. In spite of appearances, almost no one battles this image of an American woman.

In 2014, the Civitas Association in the USA created a series on YouTube entitled "Stereotypes in Commercials: Household Goods". The first advertisement in the series is for the bleacher "Clorox". It begins with the words: washing is nothing new. Your grandmother washed, your mom washed and now you are washing. The only thing that changed is the wash-board, laundry detergents and clothes, but the thing that has never changed... Unfortunately, this one thing is not a stereotype saying that - the woman is responsible for the washing, but the bleacher, which she should buy beforehand. [CivitasAssocation, 2014]. Unfortunately, this advertisement is an example of a typical marketing spot focused exclusively on sales figures rehashing stereotypes. However, Civitas Assocation designed a spot that deserves special attention. This advertisement was created for the occasion of St. Valentine's Day, which is very popular in the United States. Its broadcaster is FTD - a florist. The plot of this advertisement is not complicated. A couple sits on the sofa and answers questions asked by someone. They explain what St. Valentine's Day is for them. At some point, the man answers: "I think we agree, that on this special occasion we should do something together". Suddenly the indignant woman speaks "but I thought, that we are partners and we always should do everything together" This short spot shows, that a woman has to act as the one who must do a lot of things namely: to take care of the man and the house [CivitasAssocation, 2014].

These types of stereotypes are broken by people from Procter\&Gamble, who, in 
their advertisements show, that women are splendid. 100 days before the Olympics in Rio de Janerio in 2016, they broadcast the first advertisement as a part of a global campaign under the motto "Thank You Mom". This is another edition of the same campaign under this motto. The main theme of the campaign was a mother supporting Olympians in the trainings and preparations to competitions. In this case, Procter\&Gamble created a 2-minute spot in which they showed how much support mothers of the athletes give them in their everyday life - in a car accident, during an airplane turbulence or before the oncoming storm. Advertisement ends with a motto "It takes someone strong to make someone strong". The adverts of Procter\&Gamble show strong women breaking the stereotype of a perfect homemaker [Cause Marketing, 2016].

The same tactics was applied by P\&G 100 days before the Olympics in PyeongChang in 2018 presenting a spot entitled "Love Over Bias". It consists of several short scenes showing the battle of athletes with prejudices. In one of them, there is a teenage girl who lives in a culture where femininity excludes rivalry [Procter \& Gamble, 2017]. The campaign is a part of a bigger campaign, in which the company uses the force of advertising to start a discussion on the important issues such as prejudice. P\&G is promoting debates on the topic of gender discrimination (Ariel Share the Load, Always Like a Girl, SK-II Marriage Market Takeover, Secret's Ladies' Room Stress Test and We See Equal), race (The Talk) and sexual orientation (Vicks Touch of Care) [Procter \& Gamble, 2017a].

The campaign "Always Like a Girl" played a particularly important role in suppressing taboo about menstruation and inequality of sexes in American society. This series of advertisements, was shown not only in the United States, but also in Europe. In the P\&G report it is written: "Those ads tackle important issues like girls' confidence, while others break down stereotypes and set new expectations by portraying characters in a gender-equal setting. The campaign, has a unique voice that connects with consumers, builds the business and contributes to a better world" [Procter \& Gamble, 2017b, p.17]. Thanks to the Internet these advertisements reached millions of people in 180 countries in the entire world. It is difficult to estimate how many people watched this spot in America because it was on Television, Facebook, Twitter and YouTube at the same time. "Like a Girl" deals with an issue of playground stereotypes about running, throwing or fighting "like a girl" asking, "When did doing something 'like a girl' become an insult?"

"Keep going like a girl" is a series of adverts focused on the needs of girls all over the world. The creators of these advertisements wrote: At puberty, $50 \%$ of girls feel paralyzed by the fear of failure, with $80 \%$ of girls feeling that societal pressure is the cause of this fear." This information is based on a 2017 study among US girls aged 16-24. Moreover, "This leads to girls avoiding trying new things because they're too afraid to fail. But the truth is, failing is a good thing!" [Alwaysa.com, 2017]. For 30 years "Always" being the part of $P \& G$ syndicate teaches girls in the entire world to be confident and believe in themselves. It shows them, that being a woman is not a reason to feel weak or inferior. Gender does not determine the skills and success. A research group co-operating with "Always" carried out an experiment among Americans in different age groups. They divided them in 4 groups - young women, young men, boys in school age and their friends (girls between 10-12 years). The researchers asked them to do simple activities: "Show how a girl runs and how a girl throws" Both male and female did the same thing. They lightly bended legs at knees, did not put any effort into it and they made high pitched sounds. The boys imitated their female friends and sisters doing exactly the same thing. Only girls did not see the difference between their own behaviour and male behaviour. They ran decisively, they threw with all certainty. They were not delicate, lost or disoriented during this activity. Simply they gave everything they could. This advertising campaign shows that being a woman is not a worse option, and that the so-called weak sex is a myth. Someone labeled women this way and it is hard for them to get rid of it.

The campaigns described above show, how many socially important issues still remain in the sphere of taboo. "Always" tries to fight with the gender stereotypes and dis- 
crimination of women in various ways. Although the low context culture is characterized by strong liberalism, there are still spheres of public life, which are full of mysticism of taboo. Of course, this is a completely different kind of mysticism than the one in Hindu society. Americans are not afraid to say that women are strong. Procter\&Gamble says "we want to remind women about their value." They do not have to convince all society, that women have equal rights. They want to remind women about their value.

\section{Elements of advertising transmission in high and low context culture - sum- mary}

Without a doubt, the context of culture impacts the contents of the transmission of advertising. If the creators of a contemporary advertising forgot about this, their effort would be in vain. The large companies such as $P \& G$ try to reach the customer in various ways using broad sociological knowledge and planned activities. They choose topics, which are treated as a social secret, not only to teach something good as an act of philanthropy but also to enrich transmission, to be one step ahead of the competition, and to be remembered by the customers.

The article shows that transmissions differ according to the context of the culture that they originate from. The American advertisement is characterized by transparent and very literal language. It does not have to have a great deal of verbal content (that slowly becomes the norm for the contemporary advertising), and the visuals are fast, full of emotions and realism but also effective. Growing sales and greater interest in campaigns within the social media is the proof of their effectiveness. However, American advertisement does not aim to break taboos as much as Indian advertisement. Despite the fact that the subjects discussed are important from a sociological point of view, they refer more to suppressing of the stereotypes rather than breaking taboos.

Indian advertising market on the other hand, has a completely different approach. It exists in the realm of a high context. It means that the meaning is not transmitted directly. Language is full of euphemisms. Advertising slogans are less literal than American and they are full of double meanings. The background of transmission is very real, it imitates everyday life. Due to this approach, receivers can identify with the characters in advertisement more easily. They can compare their own life experiences with what is on the screen, and thanks to a strong contextual transmission of the advertisement, it is more understandable for the receiver. Indian adverts are as efficient as American, still they discuss a much greater deal of uncomfortable subjects. They show Hindu, how much should be changed in their life in order to raise the standard of it. However, breaking taboo through advertisement is still on a small scale and it is hard to speak about it in terms of real social change in Hindu culture.

\section{Summary}

Each culture possesses its own values and the norms of social life. People learn them all their life. These patterns are evolving even a few times in the life cycle of an individual. They are changing under the influence of different external conditionings. Nevertheless, at the border of each society, and within each culture there are rules and values, which are strongly guarded and reluctantly changed. There are also topics, which have been the subject of taboo for many generations. The marketers are reluctant to choose taboo subjects as the themes for their advertisements. Broadcasters and receivers are afraid of these controversial topics. In spite of this, big companies are willing to create advertising transmissions based on the subject of taboo more often than in the past. They want to make attractive transmission, to show something, that so far was forbidden (forbidden is always interesting) and inaccessible. Due to this approach, advertising is more effective and it brings larger profits. Of course, there are more reasons for breaking taboos in advertisements but the arguments stated above show the incentive to push cultural boundaries in society by the marketing tycoons. 
The article includes the analysis of brands known worldwide. "Ariel" is a washing powder not only on the Hindu market but also on American and even Polish market. Sanitary napkins called "Always" are used by women at every latitude. The broadcasters of these advertisements realize the variety of the markets, on which they broadcast transmissions. Taking into consideration cultural context, they create such transmissions that will engage consumers and inspire them to change and have an opinion in their own community. What is more, while choosing taboo subjects companies should realize that their main goal is to motivate a social discussion on the subject of taboo. In this way, they will gain not only the loyal supporters but also loyal customers. It is worth mentioning, that the involvement of the consumer has the largest impact on the success of a campaign. During campaign planning, cultural context of the receiver should be considered in order to make the multiple displacements of social borders decisive but not too strong and in accordance with social values. Therefore, it is worth using advertising for cultural communication.

\section{REFERENCES:}

AFEK J. (2013), Kulturowe i językowe uwarunkowania chińskich przesądów i tabu, Poznań, UAM. ALWAYS.COM (2017) [online: April 7, 2018], https://always.com/en-us/about-us/likeagirl-how-it-all-started; BBDO India (2015) [online: April 7, 2018], http://www.bbdoindia.com/\#!\&pageid=0\&itemid=37;

BBDO India (2016) [online: April 7, 2018], http://www.bbdoindia.com/\#!\&pageid=0\&subsection=3\&itemid=49; BIENIAS M. (2016), Reklama w Indiach nadrabia zaległości [online: April 7, 2018], https://marketingprzykawie. pl/artykuly/reklama-w-indiach-nadrabia-zaleglosci/;

BOSKI P. (2009), Kulturowe ramy zachowań społecznych. Podręcznik psychologii międzykulturowej, Warszawa. BRALCZYK J. (2004), Język na sprzedaż, Gdańsk, Gdańskie Wydawnictwo Psychologiczne.

BRETT J. M. (2009), Negotiating globally, San Francisco.

Cause Marketing (2016), P\&G 'Thank You, Mom' Campaign Ad: "Strong" (Rio 2016 Olympics) [online: April 5, 2018], https://www.youtube.com/watch?v=rdQrwBVRzEg;

CISMAS S. C. (2010), The impact of American culture on other cultures: Language and cultural identity, AIKED'10 Proceedings of the 9th WSEAS international conference on Artificial intelligence, knowledge engineering and data bases.

CivitasAssocation (2014), Stereotypes in Commercials: Household Goods: [online: April 5, 2018], https://www. youtube.com/watch?v=Ake1X_qP5AU;

COHEN R. (1997), Negotiating Across Cultures: International Communication in an Interdependent World, Washington D. C., United States Institute of Peace Press.

DĄBROWSKA, A. (2008), Zmiany obszarów podlegających tabu we współczesnej kulturze, „Język a kultura” tom 20, Wrocław.

DUDA A. (2005), Reklama w teorii kultury - przegląd wybranych stanowisk, „Kultura i Edukacja”, nr 1.

FERSHTMAN CH., GNEEZY U., HOFFMAN M. (2011), Taboos and Identity: Considering the Unthinkable," American Economic Journal: Microeconomics 3".

FISKE A. P,TETLOCK P. E., (1997), Taboo Trade-offs: Reactions to Transactions that Transgress the Spheres of Justice, "Political Psychology", 18(2).

Guarian Fashion (2011), Benetton's most controversial adverts [online: May 6, 2018], https://www.theguardian. com/fashion/gallery/2011/nov/17/benettons-most-controversial-adverts;

HALL E. T. \& HALL M. R. (1987), Understanding Cultural Differences, New York.

LEŚNIAK-MOCZUK K. (2015), Kobieto, kim jesteś we współczesnym świecie?, „Nierówności Społeczne a Wzrost Gospodarczy", nr 43.

MACH Z. (2002), Tabu, [in:] Encyklopedia socjologii, tom 4, Warszawa, Oficyna Naukowa.

NISHIMURA S., NEVGI A. SEPPO TELLA S. (2008), Communication Style and Cultural Features in High/Low Context Communication Cultures: A Case Study of Finland, Japan and India. Proceddings of a subject-didactic symposium in Helsinki on Feb 2, part 2, Research Report 2009.

PANASIUK I. (2009), Kulturowe aspekty tabu (na przykładzie tłumaczeń tekstów literackich rosyjskiego post- 
modernizmu), [in:]Dąbrowska A. (ed.), Język a kultura 21: Tabu w języku i kulturze, Warszawa.

Procter \& Gamble (2017), Love Over Bias [online: April 5, 2018], https://www.youtube.com/watch?v=JSWyrR4gXkw;

Procter \& Gamble (2017a), 2017 Citizenship Report Released [online: April 5, 2018, ]https://us.pg.com/who-weare/citizenship/2017-citizenship-report;

Procter \& Gamble(2017b), 2017 Citizenship Report. EXECUTIVE SUMMARY [online: April 5, 2018]www.pg.com/ citizenship; Rothermund D. (2010), Indie. Nowa azjatycka potęga, Warszawa.

RUSSEL T., LANE R. (2000), Reklama według Ottona Kleppnera, Warszawa, Felberg SJA.

SALLEH M. L. (2005), High/Low Context Communication: The Malaysian Malay Style, Association for Business Communication Annual Convention.

SZTOMPKA P. (2012), Socjologia. Analizaspołeczeństwa, Kraków, Znak.Victor D. A. (1992), International Business Communication, New York, N. Y.: HarperCollins.

WASILEWSKI J. S. (2010), Tabu, Warszawa, Wydawnictwo Uniwersytetu Warszawskiego.

WEIDER D. L., PRATT, S. (1990), On Being a Recognizable Indian Among Indians, in: D. Carbaugh (Ed.), Cultural Communication and Intercultural Contact, New York.

WishperIndia (2014) [online: April 5, 2018], https://www.youtube.com/watch?v=5s8SD83ILJY;

ZIĘBA A., (2008), Język a kultura. Komunikacja werbalna w wybranych polskich, brytyjskich i amerykańskich programach telewizyjnych, „InvestigationesLinguisticae”, Vol. XVI, Poznań. 